\title{
RELATION TO INTRAMUSCULAR CONNECTIVE TISSUE PROPERTIES TO CT-VALUES IN LONGISSIMUS THORACIS MUSCLE OF HUNGARIAN SIMMENTAL CATTLE
}

\author{
G. Holló $\dot{o}^{a *}$, B. Húth ${ }^{a}$, E. EGRI ${ }^{\mathrm{a}}$, I. Holló $\dot{O}^{\mathrm{a}}$ and I. ANTON ${ }^{\mathrm{b}}$

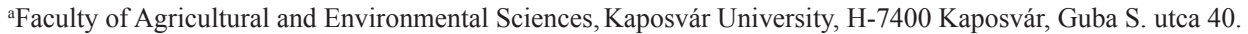 \\ Hungary \\ bNARIC-Research Institute for Animal Breeding, Nutrition and Meat Science, H-2053 Herceghalom, \\ Gesztenyés út 1. Hungary
}

(Received: 27 September 2017; accepted: 11 January 2018)

\begin{abstract}
Intramuscular connective tissue plays an important role in determining meat tenderness. The objective of the research was to compare the collagen/hydroxyproline content and X-ray Computed Tomographic (CT) connective tissue proportion of longissimus thoracis (LT) muscle in Hungarian Simmental bulls and cows. Animals $(\mathrm{n}=24)$ were slaughtered at similar live weight (bulls: $530.6+44.7 \mathrm{~kg}$, cows: $527.3+53.5 \mathrm{~kg}$ ) under standard commercial conditions in Hungary. After $24 \mathrm{~h}$ chilling, LT samples were taken from the right half carcass at the $12^{\text {th }}$ rib. CT examinations were carried out with a 16-slice CT system (slice thickness: $5 \mathrm{~mm}$ ). Samples were scanned at different user-selectable tube voltages e.g. low: $80 \mathrm{kV}$ and high: $140 \mathrm{kV}$. CT value at LT muscle area of each mixed scan $(80$ and $140 \mathrm{kV})$ was determined. Volumetric connective tissue content was measured (above $200 \mathrm{CT}$ value) as well. Following CT, the hydroxyproline/collagen content and intramuscular fat content of LT were determined. Cows had lower carcass weight (247 kg vs $295 \mathrm{~kg}$ ), EU conformation score (3.5 vs 5.5), and fatness score (4.2 vs 5.9) than bulls $(\mathrm{P}<0.01)$. Bulls had higher LT area, but intramuscular fat content was similar for bulls $(2.8 \pm 1.9)$ and cows $(2.7 \pm 2.0)$. On the other hand, bulls had lower $\mathrm{CT}$ intramuscular connective tissue proportion in LT compared to cows $(0.4 \pm 0.2 \% \mathrm{vs}$ $0.7 \pm 0.3 \% \mathrm{P}<0.01)$. The same tendency could be observed for the collagen content $(0.5 \pm 0.2 \%$ vs $0.7 \pm 0.1 \% \mathrm{P}<0.01)$. Correlation between the CT connective tissue proportion of $\mathrm{LT}$ and collagen content was $\mathrm{r}=0.8(\mathrm{P}=0.000)$. There was a weak positive correlation between slaughter age and CT connective tissue as well as collagen content of LT $(\mathrm{r}=0.3-0.4, \mathrm{P}<0.05)$. In conclusion, intramuscular connective tissue proportion in LT increased with slaughter age, and older cows had higher collagen and connective tissue proportion than bulls. Mixed CT scans can be used for the analysis of intramuscular connective tissue content.
\end{abstract}

Keywords: Hungarian Simmental, longissimus thoracis, intramuscular connective tissue, X-ray computed tomography

There are several factors including genetic background of the animal, time of feeding, diet, age, stress, chilling rate, and aging of the product influencing tenderness of beef. With such a variety of factors affecting tenderness, improvement and prediction of this trait is not easy.

Moreover, no rapid and non-destructive measurement of tenderness is currently available. The main methods currently employed to predict beef tenderness are consumer taste panel assessment and the Warner-Bratzler shear force (WBSF) method. Sensory panel

\footnotetext{
* To whom correspondence should be addressed.

E-mail: hollo.gabriella@sic.ke.hu
}

This is an open-access article distributed under the terms of the Creative Commons Attribution-NonCommercial 4.0 International License (https://creativecommons.org/licenses/by-nc/4.0/), which permits unrestricted use, distribution, and reproduction in any medium for non-commercial purposes, provided the original author and source are credited, a link to the CC License is provided, and changes - if any - are indicated. 
analysis is a direct evaluation method, but it is time-consuming and has less repeatability (SHACKELFORD et al., 1995).

The WBSF method can be used to objectively determine mechanical beef tenderness (WheELER et al., 1994). Despite the objectiveness and accuracy of the method, it is difficult to routinely apply it in the meat industry. Therefore, it is necessary to develop a nondestructive, efficient, and rapid assessment method for beef quality. The major benefit of imaging based approaches is that they provide non-destructive and non-invasive measurements. Research progress in this area suggests that the prospect of being able to estimate eating and nutritional qualities of meat may not be too far away (MALTin \& CRAIGIE, 2012). X-ray Computed Tomography (CT) is a non-invasive, diagnostic tool, initially developed for use in human medicine. It has also been adopted for use in animal science as it can non-invasively measure fat, muscle, and bone in vivo in farm animals (up to $150 \mathrm{~kg}$ of live weight) (Scholz et al., 2015). In Hungary, CT has been applied - mainly for research purposes - in cattle breeding, too. CT examination of rib samples was used for the meat yield estimation of different breeds. On the other hand, with the analysis of CT data combined with EU carcass classification, the slaughter value of carcasses can be achieved more objectively (Holló et al., 2007). CT imaging is based on the attenuation of photons from an X-ray beam transmitted through the examined object. Differentiation of various materials using conventional single-energy $\mathrm{CT}$ is based on their X-ray attenuation expressed as $\mathrm{CT}$ numbers in Hounsfield units. Developments of new protocols or dual-energy scans $(\mathrm{kV})$ aim to collect better data on soft tissue composition and meat quality (KonGSRO, 2014).

Our objective was to compare the collagen/hydroxyprolin content and computed tomographic (CT) connective tissue proportion in the longissimus thoracis (LT) muscle of Hungarian Simmental bulls and cows.

\section{Materials and methods}

Altogether, carcasses from 12 bulls and 12 cows of Hungarian Simmental cattle were randomly collected at a commercial slaughterhouse. Recorded slaughter weight was $530.6 \pm 44.7 \mathrm{~kg}$ for bulls and $527.3 \pm 53.5 \mathrm{~kg}$ for cows. Average age of bulls and cows were $696 \pm 567$ days and $3042 \pm 945$ days, respectively. Carcasses were assessed by trained operator for conformation on a 18 point scale (from 1 (the poorest) to 18 (the best)). Carcasses were also assessed for fatness on a 15 point scale (from 1 (the leanest) to 15 (the fattest)) according to the EU beef carcass classification scheme with the use of subclasses.

Carcasses were chilled conventionally for 24 hours at $4^{\circ} \mathrm{C}$. After $24 \mathrm{~h}$ chilling, samples of longissimus thoracis (LT) muscle were taken from the right half carcass at the $12^{\text {th }}$ rib. All rib cuts from each carcass were vacuum packed in polyethylene bags and transported to Kaposvár University for X-ray computed tomography (CT) analysis.

CT-examination of rib cuts was performed 3 days post mortem at the Institute of Diagnostic Imaging and Radiation Oncology of Kaposvár University. Two consecutive helical scans at low- and high-energy settings $(80 \mathrm{kV}$ and $140 \mathrm{kV})$ were realised by using a 16-slice CT system (Siemens Somatom Sensation Cardiac, slice thickness: $5 \mathrm{~mm}$ ). Images from samples scanned at two different energy levels were analysed by image analysis. Images from the two energy levels were added $(80 \mathrm{kV}+140 \mathrm{kV})$. CT value at LT muscle area of each mixed scan $(80 \mathrm{kV}+140 \mathrm{kV})$ was determined. Volumetric connective tissue content was determined (above $200 \mathrm{CT}$ value) with the usage of MANGO $(3.8,2016)$ software. 
After CT examination, samples were transported to the Analytical Laboratory of the University. After removing surface fat, intramuscular fat (IMF) content was determined gravimetrically by the Soxhlet method, using petroleum ether as solvent. Hydroxyproline measurement was used to determine connective tissue (collagen) content in meat according to the method described by REDDY and ENWEMEKA (1996). Briefly, hydroxyproline content was determined by acid hydrolysis, firstly the oxidized form was reacted with 4-dimethylaminobenzaldehyde and the absorbance was measured at $560 \mathrm{~nm}$. As a standard, an aqueous solution of L-hydroxyproline was used. The amount of hydroxyproline was determined from a standard curve. Total collagen was calculated as hydroxyproline $\times 7.25$ and expressed as $g$ of collagen per $100 \mathrm{~g}$ of muscle.

Statistical analysis was performed by using IBM SPSS 20.0 software package. Bivariate correlations procedure was used for the measurement of linear association among CT data and laboratory results, and Pearson's correlation coefficient was determined as well. Through the one-way analysis of variance procedure, the effects of sex and slaughter age were analysed, separately. Differences among groups were analysed using least significant difference test $(\mathrm{P}<0.05)$.

\section{Results and discussion}

Cows had lower carcass weight ( $247 \mathrm{~kg}$ vs $295 \mathrm{~kg}$ ), EU conformation score (3.6 vs 5.5), and fatness score (4.2 vs 5.9) than bulls $(\mathrm{P}<0.01)$ in agreement with other studies comparing carcass traits in bulls and cows (Table 1).

Table 1. Summary statistics of slaughter and carcass data

\begin{tabular}{|c|c|c|c|c|c|c|}
\hline \multirow{2}{*}{$\begin{array}{l}\text { Variable } \\
\text { Sex }\end{array}$} & \multicolumn{2}{|c|}{$\begin{array}{l}\text { Hot carcass weight, } \\
\text { kg }\end{array}$} & \multirow{2}{*}{$\begin{array}{c}\begin{array}{c}\text { EU conformation } \\
\text { score }\end{array} \\
5.5 \pm 1.3^{*}\end{array}$} & \multirow{2}{*}{$\begin{array}{c}\begin{array}{c}\text { EU fat } \\
\text { score }\end{array} \\
5.9 \pm 0.4^{*}\end{array}$} & \multirow{2}{*}{$\begin{array}{c}\begin{array}{c}\text { LT area, } \\
\mathrm{cm}^{2}\end{array} \\
77.1 \pm 14.1\end{array}$} & \multirow{2}{*}{$\begin{array}{c}\begin{array}{c}\mathrm{IMF}, \\
\%\end{array} \\
2.7 \pm 1.9\end{array}$} \\
\hline & Bulls & $294.7 \pm 31.2^{*}$ & & & & \\
\hline & Cows & $247.2 \pm 29.5^{* *}$ & $3.6 \pm 1.7^{* * *}$ & $4.2 \pm 1.8^{* * *}$ & $71.1 \pm 11.7$ & $2.8 \pm 2.0$ \\
\hline \multirow{3}{*}{$\begin{array}{l}\text { Slaughter } \\
\text { age }\end{array}$} & $>1.5 \mathrm{yrs}$ & $307.4 \pm 34.7^{\mathrm{a}}$ & $5.5 \pm 1.3^{\mathrm{a}}$ & $5.9 \pm 0.4^{\mathrm{a}}$ & $72.1 \pm 9.7$ & $3.1 \pm 1.8^{\mathrm{a}}$ \\
\hline & $1.5-3 \mathrm{yrs}$ & $280.8 \pm 25.1^{\mathrm{b}}$ & $5.5 \pm 1.4^{\mathrm{a}}$ & $5.8 \pm 0.4^{\mathrm{a}}$ & $75.7 \pm 14.0$ & $3.2 \pm 2.5^{\mathrm{a}}$ \\
\hline & $3 \mathrm{yrs}<$ & $250.2 \pm 29.3^{c}$ & $3.7 \pm 1.6^{\mathrm{b}}$ & $4.4 \pm 1.8^{\mathrm{b}}$ & $71.9 \pm 15.3$ & $1.6 \pm 0.6^{\mathrm{b}}$ \\
\hline
\end{tabular}

": $\mathrm{P}<0.05$; $^{* *}: \mathrm{P}<0.01$ : means significant differences between sex; ${ }^{\text {a,b,c }}$ : means significant differences between slaughter age, $\mathrm{P}<0.05$. Conformation and fatness scores of carcasses according the EUROP grid are expressed on an 18 point scale (from 1 (the poorest) to 18 (the best)) and on a 15 point scale (from 1 (the leanest) to 15 (the fattest)), respectively. 
For bulls, the majority of carcasses were placed to conformation score $\mathrm{O}+$ (equivalent to score 6), whereas by cows the most common conformation class was P0 (equivalent to score 2). These values - due to lighter carcass weight - were lower than previously reported. Bulls had higher LT area than cows, however, differences were not significant. LT areas of bulls were similar to the values registered in crossbred Simmental bulls slaughtered at the age of 18 months (BuREŜ \& BARTOŇ, 2012). IMF content was the same for bulls (2.8 \pm 1.9$)$ and for cows $(2.7 \pm 1.9)$, and slightly lower than the minimum amount $(3 \%)$ of IMF to achieve acceptable consumer satisfaction (HoCQUETTE et al., 2010).

Higher slaughter age significantly decreased hot carcass weight in both sexes. The EU conformation and fat scores were significantly lower in the oldest animals compared to the two other age groups regardless of sex. Older animals produced carcasses with smaller LT area and lower level of IMF $(\mathrm{P}<0.001)$.

Intramuscular connective tissue (IMCT) plays a significant role in determining meat tenderness. The main component of IMCT is collagen, which determines the basal toughness of meat. Variations in the amounts of collagen in the longissimus thoracis muscle from 15 breeds of European cattle have been shown (CHRISTENSEN et al., 2011), but although these variations can be related to the texture of raw meat, no correlation with cooked meat toughness was found. According to preliminary results established by SzaŁKowsKa and ModzelewsKaKaPITUŁa (2017), the content and profile of intramuscular collagen did not influence the organoleptic quality or shear force of two beef muscles originated form Polish Holstein.

The idea that IMCT provides a background toughness not affected by preslaughter or postmortem factors has been published in recent literature (Moon et al., 2006; CHRISTENSEN et al., 2011).

Ultrasound treatment enhances tenderness and sensory attributes of meat and also affects connective tissue and collagen contents (CHANG et al., 2015). For the better understanding or analysing of distribution of IMCT, it would be desirable to introduce further novel imaging techniques.

The CT characterization of animal tissue is generally based on differences in X-ray attenuation measured in Hounsfield units (HU). HU-number of collagen is not well documented in the literature, only a few human CT studies determined the collagen density to be higher than both in muscle and fat tissue (Whitehouse, 2006). The ability to differentiate soft tissue structures within muscle is limited, because the former mainly contain small atomic numbers and show similar X-ray attenuation values. Based on our hypothesis, this material differentiation is more feasible with the usage of dual energy. Mean collagen content was $0.56+0.19 \mathrm{mg} / 100 \mathrm{~g}$, higher than in a previous study conducted by CHRISTENSEN and coworkers (2011), but similar to the findings of BUREŜ and BARTOŇ (2012).

Mean collagen content of cows was significantly higher $(0.661 \%)$ than that of bulls $(0.411 \%)$.

The same tendency could be observed for the CT connective tissue content $(0.497 \%$ vs $0.667 \% \mathrm{P}<0.05$, Fig. 1). 


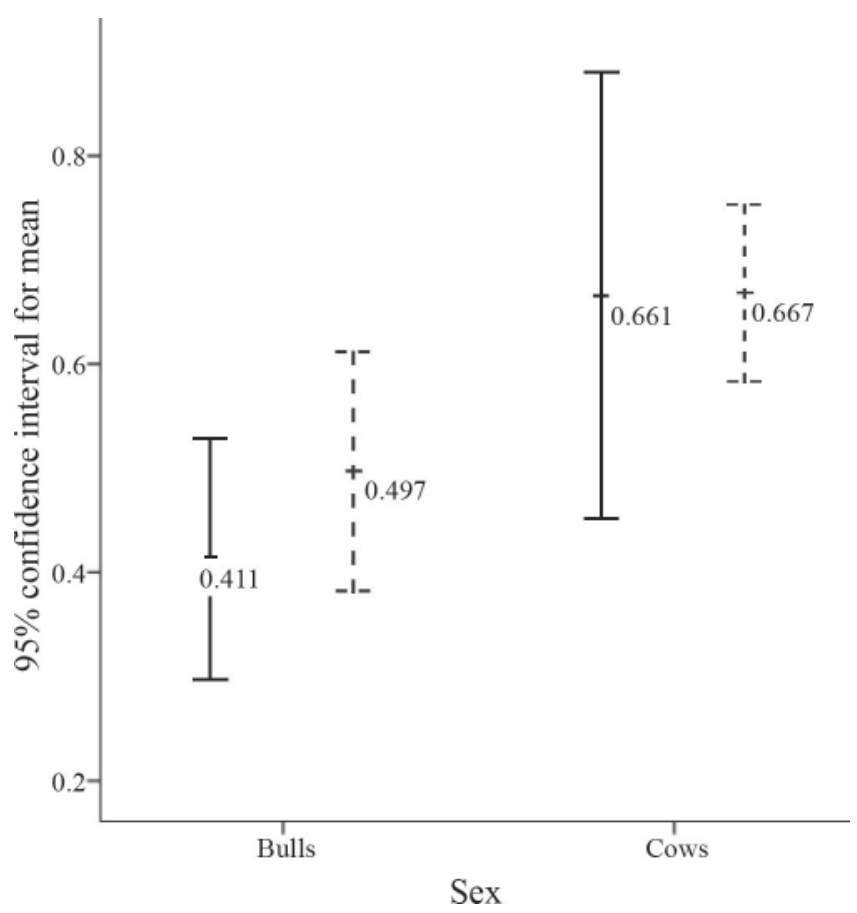

Fig. 1. Collagen content (in $\mathrm{mg} / 100 \mathrm{~g}$, solid lines) and CT determined connective tissue proportion (in $\%$, dashed lines) according to sex (mean with $95 \%$ confidence interval)

In the literature, total collagen content in muscle is affected by animal maturity (BLANCO et al., 2013). It is worthy of note, that in our study, cows were significantly older than bulls. The CT connective tissue proportion of LT correlated positively with the collagen content $\mathrm{r}=0.81(\mathrm{P}=0.000)$. A weak relationship was found between IMF content and collagen content as well as with $\mathrm{CT}$ connective tissue proportion $(\mathrm{r}=-0.30, \mathrm{r}=-0.32, \mathrm{P}<0.05)$.

In our study the age of animals had an impact on meat tenderness, which decreases as animals get older. The collagen content was lower in older animals (Fig. 2).

The highest collagen content was observed in the oldest age group $(0.65 \pm 0.11$ $\mathrm{mg} / 100 \mathrm{~g})$, which was followed by the intermediate age group $(0.59 \pm 0.09 \mathrm{mg} / 100 \mathrm{~g})$. The lowest collagen content was obtained in the youngest slaughter age group $(<1.5$ years). Similar tendency has been observed for CT connective tissue proportion $(>1.5$ yrs: $0.37 \pm 0.25 \%, 1.5-3$ yrs: $0.49 \pm 0.15 \%, 3$ yrs $<$ : $0.62 \pm 0.29 \%$ ). A weak positive correlation between slaughter age and CT connective tissue as well as collagen content of LT was noticed $(\mathrm{r}=0.3-0.4 ; \mathrm{P}<0.05)$. 


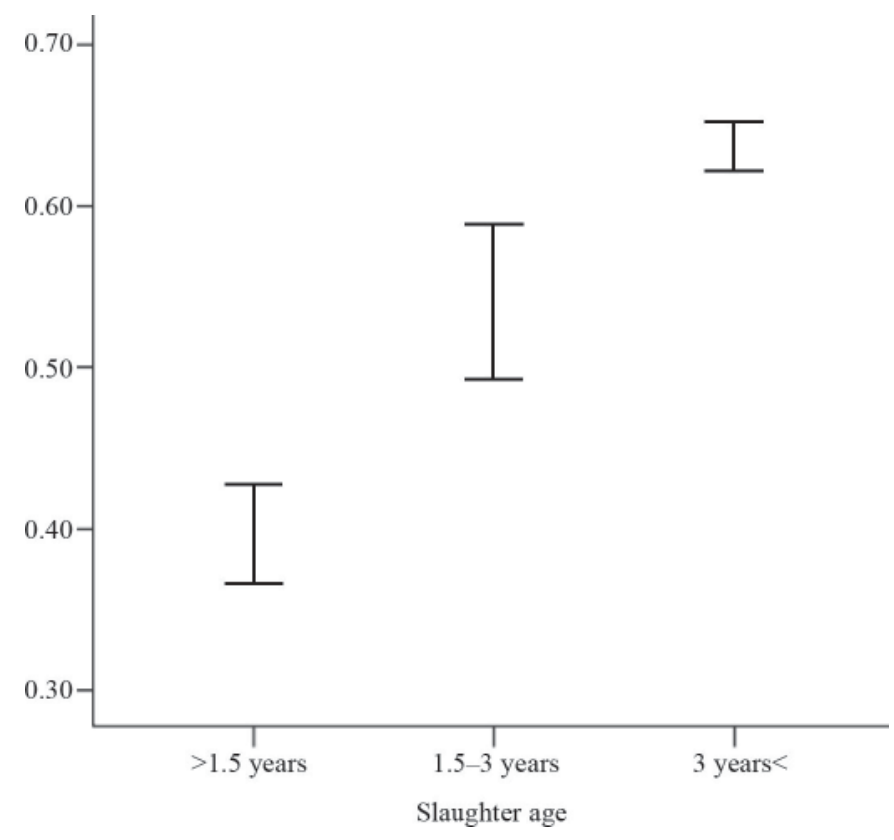

Fig. 2. High-low graph of collagen (high value) and CT determined connective tissue proportion (low value) according to slaughter age (in \%, mean with $95 \%$ confidence interval)

\section{Conclusions}

The proportion of intramuscular connective tissue (IMCT) in LT increased with slaughter age, and older cows had higher collagen and connective tissue proportions than bulls. Mixed CT scans can be used for the analysis of IMCT content. Further research is needed on this topic.

We gratefully acknowledge support from the Hungarian Scientific Research Fund (Project 111645).

\section{References}

Blanco, M., Jurie, C., Micol, D., Agabriel, J., Picard, B. \& Garcia-Launay, F. (2013): Impact of animal and management factors on collagen characteristics in beef: a meta-analysis approach. Animal, 7, 1208-1218.

Bureŝ, D. \& BARTOŇ, L. (2012): Growth performance, carcass traits and meat quality of bulls and heifers slaughtered at different ages. Czech J. Anim. Sci., 57, 34-43.

Chang, H.J., Wang, Q., TAng, C.H. \& Zou, G.H. (2015): Effects of ultrasound treatment on connective tissue collagen and meat quality of beef semitendinosus muscle. J. Food Quality, 38, 256-267.

Christensen, M., Ertbjerg, P., Failla, S., Sañudo, C., Richardson, R.I., Nute, G.R., Olleta, J.L., Panea, B., Albertí, P., Juárez, M., Hocquette, J.F. \& Williams, J.L. (2011): Relationship between collagen characteristics, lipid content and raw and cooked texture of meat from young bulls of fifteen European breeds. Meat Sci., 87, $61-65$. 
Hocquette, J.F., Gondret, F., Baéza, E., Médale, F., Jurie, C. \& Pethick, D.W. (2010): Intramuscular fat content in meat-producing animals: development, genetic and nutritional control, and identification of putative markers. Animal, 4, 303-309.

Holló, G., Szücs, E., Tözsér, J., Holló, I. \& Repa, I. (2007): Application of X-ray computer tomography (CT) in cattle production. Asian Austral J. Anim., 20, 1901-1909.

Kongsro, J. (2014): Genetic gain on body composition in pigs by computed tomography (CT): Return on investment. -in: Maltin, C., Craigie, C. \& Bünger, L. (Eds): Farm animal imaging Copenhagen 2014, Scotland's Rural College, Edinburgh, UK, pp. 28-30.

Maltin, C.A. \& Craigie, C.R. (2012): Overview to the FAIM I. meeting; Farm animal imaging opportunities and challenges. -in: Maltin, C.A., Craigie, C.R. \& Bünger, L. (Eds): Farm animal imaging Dublin 2012, Quality Meat Scotland, pp. 6-8.

Moon, S.S., YAng, H.S., PARK, G.B. \& Joo, S.T. (2006): The relationship of physiological maturity and marbling judged according to Korean grading system to meat quality traits of Hanwoo beef females. Meat Sci., 74, $516-521$.

RedDy, G.K. \& ENwEMEKA, C.S. (1996): A simplified method for the analysis of hydroxyproline in biological tissues. Clin. Biochem., 29, 225-229.

Scholz, A.M., Bünger, L., Kongsro, J., Baulain, U. \& Mitchell, A.D. (2015): Non-invasive methods for the determination of body and carcass composition in livestock: dual-energy X-ray absorptiometry, computed tomography, magnetic resonance imaging and ultrasound: invited review. Animal, 9, 1250-1264.

Shackelford, S.D., Wheeler, T.L. \& Koohmaraie, M. (1995): Relationship between shear force and trained sensory panel tenderness ratings of 10 major muscles from Bos indicus and Bos taurus cattle. J. Anim. Sci., 73, 33333340 .

SzaŁkowska, A. \& Modzelewska-KapituŁa, M. (2017): Collagen profile and tenderness of strip loin and silverside originated from Polish Holstein-Friesian bulls of the black and white variety. Acta Alimentaria, 46, 378-383.

Wheeler, T.L., Koohmaraie, M., Cundiff, L.V. \& Dikeman, M.E. (1994): Effects of cooking and shearing methodology on variation in Warner-Bratzler shear force values in beef. J. Anim. Sci., 72, 2325-2330.

Whitehouse, R.W. (2006): Computed tomography (CT) \& CT arthrography. -in: Davies, A.M., Johnson, K.J. \& Whitehouse, R.W. (Eds): Imaging of the hip and bony pelvis. Springer, Berlin Heidelberg. pp. 15-29. 